\title{
Promoting Unity in Diversity: The Imperative of Social Transformation for Managing Boko Haram Uprising in Nigeria
}

\author{
Dr. John Egharevba \\ Department of Curriculum and Instructional Technology, Faculty of Education, University of Benin, Benin City, Nigeria \\ Email: john.egharevba@uniben.edu \\ Iro Aghedo
}

Department of Political Science, Faculty of Social Science, University of Benin, Benin City, Nigeria Email: Iroaghedo@yahoo.com

\section{Doi:10.5901/jesr.2016.v6n2p41}

\begin{abstract}
Since the attainment of flag independence in 1960, Nigeria has been grappling with how to ensure unity in diversity among its various regional, religious and ethno-linguistic groups. Successive governments have strategized different mechanisms aimed at promoting national integration including the establishment of the National Youth Service Corps, building of Unity Schools, state and locality creation, implementation of a Federal Character principle, and the zoning of power positions, among several public policies. Despite these measures, Nigeria remains divided and prone to sectarian violence. In the past, many had called for the convocation of a sovereign national conference to renegotiate the terms of Nigerian unity. Currently, the Boko Haram radical Islamic sect is engaged in a rebellion against the state in the hope of establishing a theocracy governed by Sharia law. This article interrogates the role of social transformation in mitigating the Boko Haram terrorism. It argues that Islamic extremism is a manifestation of poor governance, especially the inability of governments at all levels to mainstream the importance of tolerance among the diverse social groups particularly across religious divides. The article stresses the need for peace education, principally the use of social transformation as a management tool of identity conflict by inculcating the right values in people starting from childhood.
\end{abstract}

Keywords: Unity, Diversity, Social Transformation, Boko Haram Uprising

\section{Introduction}

Efforts aimed at promoting national unity in Nigeria have been on for over five decades without much success. Today, evidences of disunity stare the country starkly in the face. Many ethnic groups have their armies in the form of Egbesu Boys, Movement for the Actualization of the Sovereign State of Biafra (MASSOB), O'odua People's Congress (OPC), Hisba, Movement for the Emancipation of the Niger Delta (MEND) and others. Some other groups are hoisting their flags in quest for self-determination as exemplified recently in Ogoni land and the troubled Bakassi Peninsula. As if these onslaughts against the state are not enough, the Boko Haram insurgents are violently agitating for the replacement of state secularity with an Islamic theocracy in Nigeria. The unprecedented violent operations of the radical Islamic sect have shattered the hope that peace would return to Nigeria with the granting of amnesty to militant youth groups in the oil-rich but volatile Niger Delta region.

But home-grown terrorism is not peculiar to Nigeria as shown by the involvement of nationals in the almost daily bombing spree across the Middle East including countries such as Egypt, Iraq, Afghanistan, Syria and others. Even the so-called developed nations are not immune to terrorism as demonstrated by the September 11, 2001 attacks on the US; the March 11, 2004 London subway bombings; and the March 29, 2010 Moscow subway bomb attacks (Sandler, 2013). However, the novelty, intensity and frequency of the Boko Haram violent campaign especially the unprovoked attacks on Christians, their fellow Muslims, students and other non-combatants are bewildering. The state's national police headquarters and the United Nations House in Abuja have also been attacked. These terrorist operations have left many dead; several people maimed; valuable property destroyed; and has triggered a wave of internal displacement, complex emergency and mass relocation from the troubled northern region. The generalized sense of insecurity and ubiquitous bomb scare has gravely undermined socio-economic activities in the region (Osumah, 2013). 
There are well-founded apprehensions that the sectarian violence by the Islamic fundamentalists could lead to the disintegration of Africa's most populous nation. So far, the response to the uprising has not succeeded since the terrorist group still executes its threats with relative ease, leading to a nationwide debate on how to manage the rebellion. The argument has polarized Nigerians into two groups, namely those who support extant use of coercion on the one hand and advocates of conciliation on the other. Supporters of a coercive counter-terrorism strategy hold that force is more effective in dealing with terrorist organizations. This position is in consonance with the ideology of the US-led 'war on terror'. However, many people who are overwhelmed by the threat of a 'looming civil war' in a country of over 160 million people contend that dialogue (with the possibility of amnesty) would be more helpful in managing the Boko Haram conflict (Aghedo \& Osumah, 2012). Over the years, the role of peace education in conflict management and as a strategy for ensuring unity in diversity in Nigeria has received scanty attention from government, policy makers as well as academics. Using the Boko Haram uprising as a case study, this article shows how the tool of social transformation can help in containing the menace of insecurity in the country, especially in the north region.

\section{Conceptual and Analytical Framework}

Two important concepts are crucial to the understanding of this discourse. They are security and social transformation. Though they feature in everyday human discourse, they sometimes mean different things to different people hence the need for conceptualization.

\section{Security}

Security is a multi-dimensional concept with variants such as social security, economic security, psychological security, job security, food security, state security, and human security. And each type is a response to a certain sort of threat. The multi-dimensionality of the concept also influences how analysts interrogate the term. For instance, Damus (1977:13) examined security from the socio-economic perspective as "the prevention of property damage, injury and loss of lives caused by military means as well as limitation of such damage, casualty and death in the event of war". This state-centric notion of security is in tandem with the Realist perspective which holds that a state is secure in as much as it possesses the power to deter potential aggressors or to defeat the aggressors if deterrence fails (Hough, 2004).

Though popular in mainstream discourse in politics and international relations, yet the state-centric notion of security is too narrow and militaristic. It places inordinate emphasis on war in the conduct of inter-state relations (Imobighe, 2012). Accordingly, there has been a paradigm shift in recent years from the Realists' emphasis on state security to human security. Advocates of the human security argue that human beings, rather than state, should be the reference object of security. Seen this way, issues such as environmental safety, education promotion, poverty reduction, employment provision, human rights protection, expansion of freedom, preservation of the well-being of persons, etc are now emphasized as core security agendas (Watson, 2011; Kumssa \& Jones, 2010). However, this securitization of humanitarianism has not gained much ground in Africa as demonstrated by the pervasiveness of grievance-based conflicts on the continent and the repressive nature of their management.

\section{Social Transformation}

Human beings everywhere are generally born into various social situations whose patterns of social relationship and cultural norms are already set by previous generations often spanning several centuries. In other to adapt, people learn the cultural 'givens'. Situations where these patterns of social relationship and cultural norms send the wrong signals due to acculturations leave room for much to be desired. Culture is the way of life of a people and this is manifested in patterns of behavior in material and non-material products of group life of members of a society (Maliki \& Momoh, 1994). However, some behaviours manifested by our adolescents today are oppositional to mainstream culture thus needing 'transformation'. This has been complicated by the current global order. Appadorai (2001) argues that globalization is characterized by objects in motion. Such objects include ideas and ideologies, people and goods, images and messages, technologies and techniques. Globalization is usually apprehended at two levels, the first being the increase in interactions and rise in trans-national flows transforming the whole world into a single space. The second level is the intensification of worldwide social relations, which link distant localities in such a way that local happenings are shaped by events far distant on the globe and vice versa.

Castes (2000) described social transformation as the different ways by which globalization forces impact upon 
local communities and national experience, economic relations, social patterns, political institutions and cultures. Going by this definition, one would discover that the contraction of the entire universe into a global village through the means of technologies has increased the rate at which materials and ideas travel across the continents. When this happens, the concerned sector or an aspect of the society can be easily influenced. Furthermore, the term 'Social Transformation' is increasingly used to describe the dynamic societal changes which generally indicate a critical stance towards older notions, norms, idea and cultural givens (Genov, 1999). Nevertheless, some scholars consider social transformation studies as a field of research that can lead to positive steps for social and political action to protect local and national communities against negative consequences of global changes.

In general, social transformation is used to apprehend and comprehend the change in society's characteristics. As such, it is a dynamic approach which happens through many ways. It could be, as Hunter (2001:22) describes, developing consciousness (person); raising awareness about social issues (person); changing actions (person); changing policy (government or organization); changing cultural attitudes; changing social structures or creating new ones; and changing material practices or creating new ones. This could be done through the family, community, governments (from local to global), corporations (non-profit and non-governmental organizations), education and knowledge, professions, the economy, the activist and political organizations, media, art, and entertainment (Castles, 2000).

Education and knowledge are veritable social structures for proper and valuable adolescents' socialization. For example, education could be used to teach people the dangers of social ills with the aim of transforming the people. As an aspect of Social Studies, social transformation shares a lot of objectives with the mother discipline. Basically, Social Studies is regarded as the transmission of relevant bodies of knowledge, attitude, manners, dispositions, skills, and values that enables an individual to survive in a growing and dynamic society. As noted by Mobolaji (1984), the core objectives of Social Studies are aimed at achieving the following:

a. Creating awareness of and sensitivity to man's environment;

b. Influencing man's attitude positively to social, cultural, economic, political values and the total environment;

c. Enabling man to acquire skills for solving societal and environment problems; and

d. Equipping voluntary participation in social and civic duties, while developing the sense of responsibility.

From the foregoing, social transformation can be used to minimize the dangers of several social problems in the Nigerian nation including juvenile delinquency, child labour, cultism, armed robbery, prostitution, ransom kidnapping, youth restiveness, sea piracy, and suicide terrorism among others. Since the youths are the most implicated in these social problems, the use of social transformation becomes imperative and crucial in educating and informing the youth and transforming them into better and more useful people to the society.

\section{Threat to National Unity: The Boko Haram Uprising}

Most states in Nigeria's North-East and North-West geopolitical zones as well as three states in the North-Central zone have been under severe terrorist attacks by the Boko Haram insurgent movement since 2009. The Islamic sect which original name is Jama'atu Allus Sunnah Lilda wati Wal Jihad is engaged in a rebellion with the aim of establishing an Islamic state in Nigeria, starting with the North where Muslims are dominant and the Sharia legal code has been in operation in 12 states since 2000. When translated literally, the Hausa and Arabic compound name 'Boko Haram' means 'Western culture is evil or sinful'. The radical sect in its narratives of grievance says it is opposed to the corruption of core Islamic ideals and virtues by globalized western culture and the practices of Nigerian government including embezzlement of funds, display of ostentatious wealth, sexual immorality, poor governance and disregard for the welfare of the people (Osumah, 2013).

However, while the claims of the Boko Haram about the excesses of state elite are indeed correct, the practices of Boko Haram members hardly reflect their proclaimed ideals, making their narratives or grievance largely rhetorical. For example, despite the group's clamour for adherence to Islamic doctrine and piety, Joint Task Force (JTF)'s raids on their hide-outs in the Sambisa and Gwoza forests in Borno State revealed a catalogue of immoral practices perpetrated by the sect including drug addiction, heroine and Indian hemp abuse, and sexual immorality (evidenced by several used and unused condoms in the enclave) (Omonobi, 2013). This is perhaps a pointer to why the sect often resorts to the kidnap of women and young girls.

Be that as it may, the emergence of Boko Haram is not as recent as often portrayed in the media. The group has been in existence since the 1960s albeit under different names and aliases. However, the insurgent movement drew public attention to itself in 2002 when Mohammed Yusuf became its leader. And in 2004, it relocated from Maiduguri in 
Borno State to Kanamma in present Yobe State where it set up an enclave known as 'Afghanistan'. A violent clash between the group and state security forces in July 2009 led to the arrest of its leader, Yusuf, by officials of the Nigerian Army (Aghedo \& Osumah, 2012). Ironically, Yusuf was later extra-judicially murdered in police custody and his bulletriddled body filmed on video. This led to a radicalization of the Boko Haram including its deployment of terror instruments and tactics such as suicide bombing (Hansen \& Musa, 2013).

After the death of Yusuf, Abubakar Shekau became leader of the group. Most members of the group are young men, mainly drawn from the Almajiri demographic cohort (Koranic pupils) and some students of tertiary institutions in the North-East zone. Most members of the terrorist group are uneducated, unemployed, and poor - the so-called "wretched of the earth" (Hansen \& Musa, 2013). Aside these male foot soldiers, membership of Boko Haram also includes young girls and women who are mainly used for errands and to spy on counter-insurgent troops and for sex slaves. In a manner reminiscent of the phenomenon of 'child soldiers' in the Sierra Leonean war, some of these young children are now used to unleash mayhem on innocent people for as little as N5,000 to set schools ablaze (Ali, 2013). In August 2013, the JTF arrested 11 Boko Haram girls who were "armed with poison and powdered substance to adulterate and poison water points and underground water reservoirs" in Maiduguri (Marama, 2013:6).

In line with terrorist operations, the Boko Haram uses diverse strategies including suicide bombing, kidnapping, jail break, arson, assassination, and others. Some of the weapons discovered in a recent JTF raid included 5 Rocket Propelled Grenade, 14 IEDS, 8 AK 47 Rifles, 9 AK 47 Magazines, 1 Rocket Propelled Grenade Charger, 163 Rifles, 3 FMG Magazines, 166 Rounds of $7.62 \mathrm{~mm}$ Special, $3.35 \mathrm{~mm}$ Bazoka, and 34 Rounds of $5.56 \mathrm{~m}$. The sophistication of these weapons shocked the military establishment according to Director of Defence Information, Brigadier-General Christ Olukolade (Omonobi, 2013). The easy availability of these weapons from Nigerian porous borders in the North and the fact that many of them can be made locally are chiefly responsible for the high human costs of the conflict. One arrested Boko Haram member confessed that he killed 23 people in two days (Marama, 2013). Indeed, the Boko Haram violent campaign resulted in 85 deaths from 35 incidents in 2010, increasing to 550 deaths in 115 incidents in 2011. And there were over a thousand Boko Haram-related deaths from 290 incidents in 2012. And over 800 lives have been lost so far in 2013 (Ndujihe, 2013).

The principal targets of the terrorists include Christian worship centres, media houses, public buildings, markets, banks, schools and security formations such as police stations and army barracks. For example, Boko Haram attack on a school in Mamudo in July 2013 killed 31 students, a teacher and one local resident resulting in the closure of all schools in Yobe State for safety reasons. A similar attack in June 2013 led to the death of seven students and two teachers at Government Secondary School, Damaturu. And a Boko Haram bombing of a Christian worship centre at Bayero University in Kano in April 2012 killed two professors and 13 others (Mgboh, 2012). Aside from the dead and the maimed, property worth millions of Naira has been destroyed. As at March 2013, Boko Haram destroyed 209 schools and property valued at N2.5 billion according to the estimate of Yobe State Governor Geidam. He added that over N4.8 billion had been spent by the state in efforts aimed at curtailing the sect (Vanguard, March 8, 2013). The cost of terrorism to Borno State is worse as over 800 schools, hundreds of police stations and government offices have been set ablaze in the Boko Haram hotbed. In fact, before the May 14 emergency rule declaration, the sect had hoisted their flags and took control of 10 local government areas in the state. The attacks on schools spell doom for Nigeria which currently has 10.5 million out-of-school children - the highest in the world (Omonobi, 2013).

The media houses have not been spared as showed by the April 26, 2012 bombing of Thisday, The Sun and Moment Newspapers' offices in Kaduna and Abuja in what has come to be described as "an attack on our much cherished freedom" (Adeyemi, 2012:3). The insurgency has led to the internal displacement of several people especially southerners who were resident in the North. Camps had to be created in the South-East for temporary accommodation of the influx of Igbo people arriving from the North who had become 'refugees in their own country'. Even the state governments of Edo, Osun and Lagos had to send vehicles to bring home their indigenes because of the sect's premeditated attacks on non-Muslims especially southerners who they see as Infidels and therefore worthy of death. In addition, several foreign nationals have been killed and a handful kidnapped for ransom by the terrorists. The attacks on United NationsHouse in Abuja killed over 20 persons mainly foreigners (Aghedo \& Osumah, 2012).

The sectarian violence damages Nigeria's national image and portrays the country in negative light to both local and foreign investors (Ojo \& Aghedo, 2013). The terrorism further widens the North-South divide in the country and breeds ethno-religious distrust, rivalry and animosity between groups especially between Muslims and Christians, and between Hausa/Fulani and others. The insurgency and counter-insurgency have had a toll on the nation's security establishment in both human and materials terms. No doubt, the violence constitutes a threat to national security, a fact that underpins and drives Nigeria's repressive and brutal response. Countless number of insurgents have been killed, 
sometimes extra-judicially since 2009.

As has been noted, intolerance is the root cause of insecurity in northern Nigeria and this is not new. Since the Maitatsine urban revolts of the early 1980s, sectarian violence has assumed a frightening dimension in Nigeria. However, the early manifestations of sectarianism were mainly intra-faith. The two main orthodox religions in Nigeria (Islam and Christianity) have been characterized by sectarianism. For example, in addition to the well-known Catholic, Anglican, and Baptist Christian denominations, thousands of new generations otherwise known as 'born-again' Christian 'sects' have sprung up throughout Nigeria especially in the Southern part of the country under the umbrella of Pentecostalism (Imobighe, 2012).

Similarly, the two main Islamic sects in Nigeria are the Tijaniyya and the Qadiriyya. A third group known as Ahmadiyya emerged in South-Western Nigeria from the two dominant sects. A few other sects such as the Izala, Jundulahhi, Fityzanul Islam, and the Maitatsine later broke out from the Tijaniyya, Qadiriyya and Ahmadiyya main sects (Alao, 2013). Unlike the fairly peaceful Christian sects, these Islamic organizations had been characterized by intrareligious disturbances and clashes since the mid 1980s arising mainly from slight differences in doctrines. However, sectarian violence has increasingly assumed an inter-religious dimension since the mid-1980s. In fact, Nigeria experienced about 12 inter-religious clashes between 1985 and 1995 including Gombe 1985, Ilorin 1986, Ibadan 1986, Kafachan 1987, Kaduna-Polytechnic 1988, Katsina 1991, Tafawa Balewa 1991, Kano 1991, Zango Kataf-Zaria-Ikara 1992, Funtua 1993, among others. The Boko Haram conflict is a further manifestation of this growing intolerance (Imobighe, 2012).

From the above analysis, the Boko Haram uprising obviously constitutes a security threat to the Nigerian nation. However, the country's militaristic approach to the insurgency including arrest, detention, proscription of group, declaration of emergency rule, and killing of members have not been able to contain the violence. For example, since the declaration of emergency rule in Yobe, Adamawa and Borno States on May 14, 2013, 30 military men and police officers have been killed in combat-related violence. Also, the counter-insurgency has led to the death of over 300 insurgents and the arrest of over 1000 according to military sources (Omonobi, 2013). But state repression fails to address the root cause of the rebellion which is intolerance and the immediate causes such as poverty, ignorance and drug abuse. The JTF Commandant in Yobe State, Colonel I.S. Alli revealed recently that many Boko Haram members abuse the drug Trammol which makes them unconscious of the enormity of their atrocities (Admosu, 2013).

The insurgents, though weakened, are still able to unleash mayhem especially at 'soft targets' with relative ease. Even, the repressive strategy of the Nigerian security establishment has fuelled some resentment in some quarters. Recently, some traditional rulers in the affected states called for the withdrawal of the JTF for its members' infringement on the rights of the people as well as the killing of some innocent citizens. The emergency rule has even led to the dispersal of the insurgent group to other parts of the country as evidenced by the recent arrest of some Boko Haram members in Lagos and Ogun States. Therefore, there is need for a rethink of the conflict management strategy to ensure sustainable peace. In line with this, we exemplify in the following section how the tool of social transformation can be used to 'tame the monster' of Boko Haram terrorism.

\section{Promoting National Unity: The Imperative of Social Transformation for Managing Boko Haram Uprising}

Social transformation, we noted earlier, is a sub-discipline of Social Studies. It deals with the reciprocal relationships between people and the various aspects of their environment. As people encounter problems in their quest to live a comfortable, orderly, and more meaningful life, social transformation becomes useful in tackling the societal challenges by helping them adapt to the ever-changing environment they live in through the acquisition of relevant knowledge, attitudes, values and practical skills. Thus, like the mother discipline Social Studies, social transformation is designed to help in providing functional and social education to Nigerian children and youths, and, hopefully, also make good citizens and patriots out of them (National Teachers' Institute, 2011). Therefore, the role of social transformation in mitigating the current high level of insecurity and ensuring unity in Nigeria cannot be over-emphasized. This enviable role can be achieved through the inculcation of relevant values such as tolerance in Nigerian citizens especially the young ones. The belief by Boko Haram insurgents and some other Muslims that adherents of other faiths aside from Islam are Infidels and therefore worthy of death is wrong and should be debunked and discouraged. Teachers, parents, traditional institutions, religious groups, non-governmental organizations and indeed government agencies have a veritable role to play in this (Gerry-Eze \& Egharevba, 2004).

Indeed Nigeria is a plural society with a very high level of ethnic, religious, and regional segmentation. However, rather than being a source of division and conflict, social pluralism can be a source of strength and development as 
shown by the experiences of some other nations such as Canada and Belgium. Like these countries, social transformation especially the teaching of peace education can be used to ensure tolerance in a divided society. Social transformation can help to inculcate in everyone that Nigeria is a secular state where people can practice their different religions without fear or molestation. Unfortunately, our school system has given more attention to foreign studies to the detriment of indigenous education. As noted by Fafunwa (1974) students in Nigeria know more about Europe and European people than Nigerians who belong to ethnic groups different from their own. To create trust and confidence among Nigerians, it is necessary to provide Nigerian intercultural education. Citizenship education has been used in many countries including the United States of America to curb social problems and build national cohesion for stable and democratic society (Iyamu, 2011; Omare, 1999; Awosolu, 1993). Nigeria should not be an exception.

Furthermore, the youths get easily mobilized by 'conflict entrepreneurs' and terrorism sponsors because they lack good knowledge of the importance of national unity. Social transformation has a role to play here. The slogan of Nigeria 'one nation, one destiny, one God' and the popular saying, "Together we stand, divided we fall" need to be sunk into the minds of our youth and the so-called elite. They should be taught and made to imbibe a sense of community development. When they realize that they have a stake in Nigeria, they will not turn around to kill and destroy what they have labored to build. As teachers, there is need for us to inculcate in Nigerians that our individual and national values and aspirations cannot be realized in an environment of insecurity, armed violence, mutual distrust and terrorism. Nigeria as a nation is today faced with continued decline in civic values and downward trend in morals. Social transformation can also be used to re-awaken civic consciousness, moral rejuvenation and create the awareness about the Constitution which says that "The Government of the Federation or of a state shall not adopt any religion as state religion" (Nigeria, 1999 Constitution, Section 10).

Importantly, the tool of social transformation can be used to create awareness in Nigerians that the world has become a global village where ideas, values, goods, services, people and their behavioural patterns move across international borders with ease through advancement in Information, communication and Technology (ICT) and migration. In today's global order, no country or local culture can be an "Island' - no people can live in isolation of other countries in the world socially, politically, economically and even technologically. Therefore, it is ignorant to designate 'Western culture as evil' or 'education as sinful' as Boko Haram claims. The tool of social transformation is well-suited to disabuse the minds of the terrorists as well as other youths of these inimical notions that are not in tune with the logic of globalization.

From the foregoing, it is clear that there is need for value re-orientation among the youths, elites and other Nigerians including clerics who preach and glorify hatred in their sermons. Currently, the youths no longer place much premium on honesty, love, integrity, mutual respect and the sanctity of human life. These values have been debased by the unbridled quest for material things and the frequent recourse to violence at the slightest provocation. Similarly, the so-called elites stop at nothing in their quest for power and wealth. They harass, kidnap, and even kill members of the opposition in the struggle for state resources which they often abuse to promote personal and sectional interests rather than the welfare of the ordinary citizens. In fact, the elites have been incapable of leading by example. Many of them even recruit the poor and desperate youths to execute their nefarious activities including ballot stuffing, political thuggery, and even assassination. To a large extent, the elites need value re-orientation as much as the youths. They need social transformation in order to imbibe the essence of governance. However, social transformation cannot be used in isolation. For peace education to be effective, the youths need to be positively engaged in profitable ventures. Thus, government overreliance on amnesty declaration for militant and criminal elements is inimical to sustainable peace-building and should be discouraged (Aghedo, 2013). Instead, there is need for youth empowerment as social transformation can only help to develop in them skills and values to survive in a dynamic society. As much as possible, the government should reduce slothfulness among the youths and discourage their employment of criminality as a survival strategy. An 'idle mind', they say, 'is the devil's workshop'. So, the government should also provide enabling environment through infrastructural development for foreign investors so that majority of the youths can be employed and be off the streets. This will help to mitigate Boko Haram terrorism.

\section{Recommendations}

The following recommendations are therefore vital for effective social transformation in Nigeria:

i. Promotion of Peace Education: as noted earlier, most conflicts including the Boko Haram terrorism happen because people are not sufficiently aware that the world is inter-dependent. Therefore, people must learn to live together, in peace and harmony. Peace building institutions must begin to promote social orientations and 
ideals for sustainable peace and stability worldwide. Though education is paramount, but it is not the only strategy for peace education.

ii. Encouragement of Judicial Independence: Unfettered justice is a sine qua non for peace and stability. A country that lacks basic justice precincts becomes a fertile ground for violent conflicts. Non-Governmental Organizations (NGOs) as well as the government must encourage an acceptable level of independence of the judiciary in the handling of Boko Haram cases.

iii. Establishment and Strengthening of Networks: Peace-keeping processes in Nigeria are often duplicated by myriads of NGOs and civil society groups working with concerted effort to grow and maintain peace. This is largely due to the lack of co-ordination among the organizations. It is thus important for NGOs to coordinate efforts aimed at Boko Haram management through a web of networks to strengthen their position, legitimacy and leverage.

iv. Localization of Peace Initiative: Many peace initiatives in Nigeria fail because the entire process is imposed rather than internally generated. This mistake has also been made in the management of the Boko Haram conflict. To obtain and sustain peace, the people affected, i.e. the local people must be part and parcel of the initiative and the instruments that are aimed at bringing peace. Otherwise, peace will be elusive and transient.

v. Engagement of Elders and Local Authorities: Most ongoing peace processes in Nigeria including Boko Haramrelated ones do not engage the creative energies and inputs of elders and other local authorities, especially opinion leaders, chiefs and kings. Often times, only major actors are summoned for peace talks leaving local authorities out of the process which makes peace proposals ineffective and difficult to implement. Thus, engaging local authorities will enhance the possibility of mitigating the Boko Haram violence.

vi. Involvement of Women in Peace-Building: as Omoyibo (2011) noted, women play cardinal roles in the peacebuilding process including the fact that they give life and preserve generations; they create linkages in society through inter-marriages; they intervene in conflict situations and deter full-blown conflicts; and they are children's primary or frontline educators and moral instructors. The Almajiri children from whom the Boko Haram draws its foot soldiers have mothers. These women have a role to play in conflict reduction. They need social awareness to realize the dangers of allowing their children to be used to perpetrate violence.

\section{Conclusion}

The paper has argued that the Boko Haram uprising constitutes a major threat to national unity and socio-economic development in Nigeria. The terrorism, as shown above, is driven mainly by ethno-religious intolerance among groups. Ironically, government over-reliance on militaristic approach in finding solution to the violence has not succeeded in engendering the much needed peace hence the need for a rethink of the conflict management strategy. The paper exemplified how social transformation can be deployed in changing the attitudes of the youths especially and other Nigerians in general to embrace tolerance in their everyday engagement with people of other faiths, creed, ethnicity and even race. Indeed, tolerance is a core value for peace, social harmony, and economic development in a globalized world.

\section{References}

Adeyemi, L. (2012). Bomb blast, an attack on freedom, says CNPP. The Guardian. April 28.

Admosu, F. (2013). The butcher of Borno. The News. August 19.

Aghedo. I. (2013). Winning the war, losing the peace: amnesty and the challenges of post conflict peace-building in the Niger Delta, Nigeria. Journal of Asian and African Studies, Vol. 48 (3): 256-278.

Alao, A. (2013). Islamic radicalization and violent extremism in Nigeria. Conflict, Security and Development, Vol. 13 (2): 127-147.

Ali, Y. (2013). We were paid N5,000 to burn schools - freed Boko Haram kids. The Nation. June 1.

Appadurai, A. (2001). Grassroots globalization and the research imagination. In Ghana Journal, Duke University. Ghana City Publishers.

Awosolu, E.O. (1993). Political development and Social Studies education in Nigeria: problems and prospects. Nigeria-Journal of Social Studies Review. Vol. 4 (2): 13-27.

Castees, S. (2000). Development, race, transformation and globalization. A paper presented at Center for Asia Pacific on Social Transformation Studies at Workshop held from 23-25 June, 1999. Available at www.theglobacite.ac.uk. Accessed on May 3, 2013.

Castles, S. (2000). Developing social transformation and globalization. A paper presented at the Centre for Asian Pacific Social Transformation Studies Workshop, 23-25, June, 1999. Available at www.theglobacite.ac.uk. Accessed on May 3, 2013. 
Damus, L. (1977). 'System reliability and national security. Peace Research Review, Vol. 7: 66-85.

Fafunwa, A.B. (1993). History of Education in Nigeria. London: George Allen and Unwin Ltd.

Genov, N. (1999). Managing transformation in eastern Europe. UNESCO - Most Paros.

Gerry-Eze, I.U. and Egharevba, J. (2004). Drug education as a vehicle for social transformation. Benin Journal of Educational Studies, Vol. 18 (1 \& 2): 43-62.

Hansen, W.W. and Musa U.A. (2013). Fanon, the wretched and Boko Haram. Journal of Asian and African Studies, 48 (3): $281-296$.

Hough, P. (2004). Understanding Global security. New York: Routledge.

Imobighe, T.A. (2012). Governance and Nigeria's national security. In Imobighe T.A. and Ebohon S.I. (Eds.). Themes and Issues on Nigerian Governance and Politics, Kuru: National Institute Press.

Iyamu, E.O.S. (2011). The role of citizenship development and education in national peace and unity. In lyamu, E.O.S. and Salami L.J. (Eds.), Peace Studies and Conflict Resolution. Benin City: Otoghagua Ent.

Kumssa, A. and Jones, J.F. (2010). Climate change and human security in Africa. International Journal of Sustainable Development, 17 (6): 453-461.

Maliki, F.A. and Momoh, S.O. (1994). Developmental psychology: an educational perspective. Ekpoma: Institute of Education, Edo State University.

Marama, N. (2013). I killed 23 people in 2 days, Boko Haram member confesses. Vanguard, June 27.

Marama, N. (2013). JTF, vigilante arrest female Boko Haram suspects, Saturday Vanguard, August 17.

Mgboh, D. (2012). Two professors, 13 others killed. Daily Sun.April 30.

Mobolaji, O. (1984). Introduction to Methodologies of social studies. Ibadan: Evans Brothers Nigeria Limited.

National Teachers' Institute (2011). Manual for the re-training of junior secondary school teachers in Social Studies: Millennium development goals (MDGs) project. Kaduna: National Teachers' Institute.

Ndujihe, C. (2013). Is Shekau really dead. Vanguard. August 20.

Nigeria, (1999). 1999 Constitution, Federal Republic of Nigeria.

Ojo, G.U. and Aghedo, I. (2013). Image re-branding in a fragile state: the case of Nigeria. The Korean Journal of Policy Studies Vol. 28 (2): forthcoming.

Omare, O. (1999). Enhancing democracy in Nigeria through citizenship education. Nigerian Journal of Social Studies Review, Vol. 8 (1): 33-39.

Omonobi, K., Okoli, A., Ndujihe C., and Idonor C. (2011). FG panel calls for amnesty. Vanguard, September 27.

Omoyibo, K.U. (2011). Developing a culture of peace. In lyamu, E.O.S. and Salami, L.I. (Eds.). Peace Studies and Conflict Resolution. Benin City: Otoghagua Ent.

Osumah O. \& Aghedo, I. (2011). Who wants to be a millionaire? Nigerian youths and the commodification of kidnapping. Review of African Political Economy, Vol. 38 (128): 277-287.

Osumah, O. (2013). Boko Haram insurgency in northern Nigeria and the vicious cycle of internal insecurity. Small Wars and Insurgencies, 24 (3): 536-560.

Sandler, T. (2013). The analytical study of terrorism: taking stock. Journal of Peace Research. Available at http://jpr.sagepub. com/content/early/2013/08/0022343313491277. Accessed on August 16, 2013.

Vanguard (2013). 209 schools destroyed by insurgents. March 8.

Watson, S. (2011). The 'human' as referent object? Humanitarianism as securitization. Security Dialogue, 42 (1): 3-20. 